IJPLE 3 (1) 2019

\title{
LAW RELATED EDUCATION IN JAPAN \\ - DEVELOPMENTS AND CHALLENGES ${ }^{1}$
}

Kyoko ISOYAMA2

\section{INTRODUCTION}

The purpose of this paper is to discuss the current state of and challenges facing LawRelated Education (LRE) in Japan. What follows defines the concept of LRE, the particular characteristics of LRE in Japan, curriculum developments in Japan and elsewhere (especially the United States of America (USA)) and, specifically, the subject of justice studies in elementary and junior high schools.

LRE in Japan has been heavily influenced by developments in the USA. Both have been affected, in a positive sense, by public legal education luminaries notably the American Dr. Isidore Starr and Yuji EGUCHI in Japan³.

Social studies in Japan was established after World War II and focused on constitutional education aimed at promoting democracy. However, this resulted in a limited understanding of the relationship between the state and individuals, given then existing hierarchical structures. LRE in Japan is an attempt to re-position legal

\footnotetext{
${ }^{1}$ A version of this paper was originally published by the United Nations Asia And Far East Institute for the Prevention of Crime and the Treatment of Offenders, as Resource Material Series. No. 105, 2018, 116-126, and is reproduced here with the publisher's approval.

${ }^{2}$ Professor, Faculty of Education, Shizuoka University, Japan

3 Yuji EGUCHI. (1993). Shakaikaniokeru 'Hokyoiku'no Juyousei: Americashakaikaniokeru 'Hokyoiku'no Kentowotoshite. Nihonshakaikakyouikugakkai. Shakaikakyouikukenkyu. No. 68. pp. 1-17. (江口勇治「社会科 における『法教育』の重要性一アメリカ社会科における『法教育』の検討を通して一」日本社会科教育学会『社会 科教育研究』No. 68, 1993 年, pp. 1-17.)
} 
citizenship as a concept that includes horizontal relationships between society and the citizen and between citizen and citizen ${ }^{4}$.

\section{THE IDEA OF LRE}

\section{A. Definition of LRE}

According to the relevant legislation in the USA LRE is defined as "education to equip non-lawyers with the knowledge and skills pertaining to the law, the legal process, and the legal system, and fundamental principles and values on which these are based." 5

Since then, LRE in the USA has been actively positioned as one of the educational subjects to be addressed throughout the country as a whole. The U.S. Department of Education promotes the concept nationwide.

According to applicable regulations, LRE helps students "respond effectively to the law and legal issues in our complex and changing society." 6 The above definition has three components. First, the target is the non-lawyer, including children. It differs from formal law-school education, which is targeted to those seeking to become lawyers themselves. Secondly, it addresses legal rules themselves, and the legal

\footnotetext{
${ }^{4}$ Kyoko ISOY AMA. (2006). Shakaikaniokeru Hokyoikuno Hokousei. Nihonshakaikakyoikugakkaishuppanproject, ed. Shinjidaiwo Hiraku Shakaikano Chosen. Daiichigakushusha. p. 238. (磯山恭子「社会科における法教育の方向性」日本社会科教育学会出版プロジェクト編『新時代を拓く 社会科の挑戦』2006 年, p. 238.)

${ }^{5}$ Public Law 95-561. (1978). Law-Related Education Act of 1978.

6 American Bar Association Division for Public Education. Law-Related Education Network. (https://www.americanbar.org/ groups/public_education/resources/law_related_education_network.html)(visit; 2018.1.5).
} 
process including the operation of the legal system itself. It also has regard to the fundamental principles and values on which law and the legal system are based. LRE in the USA deals with the law in its broadest sense, not being limited to the substantive rules of civil and criminal law, but addresses dynamic, active and working laws, processes, and values. Thirdly, it fosters 'knowledge and skills' that can be used in a practical sense. In addition to gaining knowledge, it is important to encourage skills acquisition and attitude formation to empower citizens to take a more active role in society.

From the late 1960s to the latter half of the 1970s, in the USA, with the backdrop of civil rights struggles, there was a growing awareness that it was important to engage in LRE to promote active citizens but also to address perceived problems of discrimination, corruption and juvenile delinquency. ${ }^{7}$ With such impactful events as the Watergate scandal and widespread social problems, a diverse and concrete approach to citizenship including civil rights (and duties) and multicultural education was actively discussed. In addition, LRE was aimed at recognizing the meaning and value of justice. Moreover, the acquisition of knowledge and skills was seen as important, providing tools to help citizens to identify and possibly solve legal and related problems. Secondly, and specifically, LRE was also intended to address and

\footnotetext{
${ }^{7}$ Report of the American Bar Association Special Committee on Youth Education for Citizenship. (1975). LawRelated Education in America: Guidelines for the Future. American Bar Association. pp. 3-4.
} 
prevent juvenile delinquency. Crime and anti-social behavior increased significantly during the latter half of the 1960s, and was seen as a major and growing problem. ${ }^{8}$

\section{B. LRE - Goals, subject matter and methods}

One of the principal goals of LRE is therefore to develop legal literacy. This concept rests on two main ideas ${ }^{9}$. First, LRE should be recognized as an integral part of each person's basic education for becoming a knowledgeable and responsible citizen. Secondly, promoting the 'legal literacy' of citizens safeguards our democratic institutions.

According to LRE: A Crucial Component of American Education presented by the American Bar Association Special Committee on Youth Education for Citizenship, "legal literacy is an essential prerequisite if one is to function effectively as a citizen in private and public affairs." 10

Legal literacy is also concerned with the idea that law is not static - it changes to reflect the needs and realities in wider society. As well as covering what the law actually says, a greater awareness of the role law plays can lead to more developed reasoning and analytical skills along with ethical awareness. In addition, appreciating how the law functions and the processes associated with it can help with the understanding of the purpose of law in its operational context.

\footnotetext{
8 Ibid. p. 3.

9 Study Group on Law-Related Education. (1978). Final Report of the U. S. Office of Education. U. S. Government Printing Office. (ED175 737). p. xi.

${ }^{10}$ Ibid. p. 51.
} 
Charlotte C. Anderson states that the following are characteristic outcomes of LRE ${ }^{11}$.

(1) Perceiving law as promotive, facilitative, comprehensible, and alterable

(2) Perceiving people as having potential to control and contribute to the social order

(3) Perceiving right and wrong as issues all citizens can and should address

(4) Perceiving the dilemmas inherent in social issues

(5) Producing reflective decision-makers and problem solvers who make grounded commitments

(6) Giving reasoned explanations about commitments made and positions taken

(7) Being socially responsible conflict managers

(8) Being critically responsive to legitimate authority

(9) Being knowledgeable about law, the legal system and related issues

(10) Being empathetic, socially responsible and considerate of others

(11) Being able to make mature judgements in dealing with ethical and moral problems

11 Anderson, Charlotte C. (1980). Promoting Responsible Citizenship Through Elementary Law-Related Education. Social Education. Vol. 44-5. p. 384. 
Anderson states that "the major goal of LRE is to move children away from negative characteristics and toward characteristics more in keeping with the demands of democratic stewardship." 12 She also states that "LRE is congruent with good social studies in general and is a means of fostering the goals of citizenship education." 13

According to the Study Group report on LRE, the likely coverage for an effective LRE programme will include some or all of the following: ${ }^{14}$.
(1) legal principles and the values on which they are based
(2) the Bill of Rights and other constitutional laws
(3) the role and limits of law in a democratic society
(4) conflict and dispute resolution
(5) the role of law in avoiding conflict and disputes
(6) development and administration of rules
(7) the administration of the criminal and civil justice systems, and their strengths and weaknesses
(8) informal laws
(9) authority, freedom, enforcement, and punishment

12 Ibid. p. 383.

13 Ibid.

14 Study Group on Law-Related Education, op.cit. pp. 1-3. 
(10) law as a vehicle to illuminate and resolve social and political issues

(11) areas of law that affect the daily lives of citizens

(12) international relations, anthropology, and economics

As can be seen from the above points the content of LRE is not therefore limited in the narrow sense to substantive rules found in statutory or case law but rather covers wider-reaching content such as principles of democracy, dispute resolution, legal process, custom and practice and the daily impact of law and the legal system.

The educational methods of LRE lend themselves to inquiry and problem-based learning and other experiential approaches to study ${ }^{15}$. LRE encompasses many educational strategies and teaching methods such as moot court simulation and mock trials. The LRE curriculum, as detailed below, provides rich educational material and lends itself to class participation and interactive study methods.

\section{THE DIVERSITY OF THE LRE CURRICULUM}

\section{A. Features of LRE Curricular}

According to the booklet Youth for Justice; Making a Difference ${ }^{16}$ published by the American Bar Association, a specific LRE curriculum was developed during the 1990s

\footnotetext{
15 Ibid.

${ }^{16}$ American Bar Association. Youth for Justice; Making a Difference.
} 
supported financially by the Office of Juvenile Justice and Delinquency Prevention, part of the US Department of Justice.

The focus is to ensure that the "Youth for Justice is a unique national initiative that uses the power of active learning about the law to build upon the vitality of young people and to address the risks of being young in America today." 17 This initiative builds on the overall aims of LRE as outlined above, including developing a greater sense of citizenship among youth with a view to tackling juvenile delinquency.

\section{B. Types of LRE curriculum}

A number of bodies, principally in the USA, have developed LRE curricula. These include:

\section{Foundations of Democracy ${ }^{18}$}

The Center for Civic Education developed its Foundations of Democracy also during the 1990s and has revised the curriculum many times. This can be described as a 'legal values' model. The knowledge component is aimed at recognizing the system of constitutional democracy and the basic principle and values this is based on. Foundations of Democracy targets the K-12 grade. Foundations of Democracy teaches four concepts: 'Authority', which focuses on making law in society; 'Privacy', which

17 Ibid. p. 5.

${ }^{18}$ Center for Civic Education. (1998). Foundations of Democracy; Upper Elementary, Middle School, High School. 
focuses on individual freedom; 'Responsibility', which focuses on how to assign and accept responsibility; and 'Justice', which focuses on applying law in society.

\section{2. ${\text { Street } \text { Law }^{19}}^{19}$}

Building on the pioneering work at Georgetown University's School of Law in the 1970s, Street Law Inc., a nonprofit group based in Washington DC, further developed what is now an internationally recognized model of LRE known, now globally, as Street Law.

Whilst there is no one recommended curriculum the many Street Law programmes, that exist across the civil and common law worlds and in both the northern and southern hemispheres, cover a wide range of subjects and issues. The common denominator is the focus on teaching and learning the law through interactive classes that deal with the law as its affects everyday life. Much of this focuses on young people, often in schools, but there are also many examples of Street Law sessions that work with others including in prisons and community centres and often involving 'training or trainers' initiatives. Another common feature of Street Law programmes is that the sessions are often designed and delivered by law students under the supervision of professionally qualified lawyers. In this way the law students learn, as well as the community groups involved, by having to research and present the relevant subject matter.

\footnotetext{
${ }^{19}$ National Institute for Citizen Education in the Law. (2005). Street Law; A Course in Practical Law, Seventh
} Edition. West Publishing Company. 


\section{Project Citizen $^{20}$}

Again, in the 1990s, the Center for Civic Education developed Project Citizen. This can be best described as 'community activities' model. The goals of Project Citizen are to enable students to express their opinions, to decide which institution of the government should deal with certain problems, and to influence government policy decisions. This initiative has six steps. Specifically, these are 'clarifying the policy problems of the community', 'choosing the research theme', 'gathering information on the research theme', 'creating the portfolio', 'presenting the portfolio', 'evaluating the learning experience', and 'the class portfolio'. While learning about legal participation, Project Citizen has the distinctive feature of requiring actual participation in the community as a citizen.

\section{I'm the People $^{21}$}

The American Bar Association's initiative, Youth Education for Citizenship, has developed a programme known as I'm the People. This sees an integration of all the other models described above. The curriculum is aimed at recognizing a constitutional democracy, essential concepts such as law, power, justice, freedom, and equality, pursuing rights and responsibilities under the law, resolving conflict and discussing and analyzing public policy. The skills acquisition component is aimed at developing

${ }^{20}$ Center for Civic Education and the National Conference of State Legislatures. (2008). Project Citizen.

${ }^{21}$ American Bar Association Division for Public Education. (1995). Making Rules \& Laws. American Bar Association Division for Public Education. (1995). Resolving Conflict. American Bar Association Division for Public Education. (1996). Serving the Community. American Bar Association Division for Public Education. (1996). Influencing Public Policy. 
critical thinking and the ability to gather and analyse material and to participate effectively in debates and discussions. The programme looks at: 'Making Rules \& Laws', 'Resolving Conflicts', 'Service in the Community', and 'Influencing Public Policy'.

\section{LRE IN JAPAN}

\section{A. Reasons for Introducing LRE in Japan}

As we have seen it is important for citizens to improve their legal literacy, as it is a necessary component of citizenship. Developing of legal literacy for citizens in Japan is significant from three viewpoints: the social, the institutional and the educational.

Social background includes a concept known as the 'legalized society'. A legalized society is one established on the basis of a legal relationships. According to Shigeaki Tanaka, a representative researcher on legalization theory in Japan, two factors have contributed to the progress of a legalized society in Japan ${ }^{22}$. The first is the rapid urbanization and progress of industrialization that has taken place since the latter half of the 1960s. The second concerns international considerations including global trading arrangements and the presence of multinational corporations.

The idea here is that where a legalized society has developed, not only can we build clearer legal relations but also have a more effective dispute resolution system. In

\footnotetext{
${ }^{22}$ Shigeaki TANAKA. (1996). Gendaishakaito Saiban: Minjisoshono Ichito Yakuwari. Kobundo. p. 1. (田中成 明『現代社会と裁判一民事訴訟の位置と役割一』弘文堂，1996 年，p. 1.)
} 
order to do this, it is extremely important for every citizen to develop their legal literacy as a condition of citizenship. Specifically, each citizen is required to acquire the awareness and ability to participate in and make informed choices about legal matters.

Institutional considerations include the relatively recent introduction of the lay judge (saiban-in) system in Japan. The establishment of the Justice System Reform Council in July 1999 provided the opportunity to introduce lay judges and in June 2001, the Council finalized this system. In May 2009, this development was launched to give ordinary citizens a direct role in the criminal judicial process. Changes in institutional provision can be considered as one of the developments of the legalized society. In such a society, not only lawyers, but also citizens are required to take up active legal citizenship. The Justice System Reform Council has also expressly recognized the importance of LRE ${ }^{23}$.

Educationally there have been developments around LRE in Japan too. In January 2008, the Report on Improvements of Courses of Study at Kindergarten, Elementary School, Junior High School, High School and Special School, etc." was issued by the Central Council for Education. ${ }^{24}$ This states that LRE has an important role to play in school

23 Shihouseidokaikakushingikai. (2001). Shihouseidokaikakusingikai Ikensho: 21seikino Nihonwo Sasaeru Shihouseido. pp. 102-103. （司法制度改革審議会『司法制度改革審議会意見書一21 世紀の日本を支える 司法制度一』2001 年 6 月, pp. 102-103.)

24 Chuoukyouikushingikai. (2008). Yochien, Shogakko, Chugakko, Kotogakkoyobi Tokubetsushiengakkono Gakushushidoyoryono Kaizennitsuite(Toshin). (Report on improvements of Courses of Study at kindergarten, elementary school, junior high school, junior high school, high school and special school etc.). （中央教育審 
education. Specifically, with an early understanding of socio-economic systems such as the role of law and justice, a more sustainable society can be developed through active citizenship.

LRE in schools in Japan is addressed through a cross-curricular approach. For example, social studies classes focus, at least in part, on developing citizenship. Home economics looks at appreciating family life and the role of work. Moral education is taught based on respecting commitments, abiding by laws and other rules, developing personal responsibility, and understanding the meaning of justice for all. Particular attention is also given to solving problems.

\section{B. LRE in Social Studies ${ }^{25}$}

\section{LRE in Elementary Social Studies}

In The 2008 Elementary Social Studies Course of Study, LRE, was positioned clearly within the curriculum. In grade 3 and grade 4, students are expected to learn about: securing drinking water, electricity, gas and waste necessary for the lives of local people and the prevention of disasters and accidents in communities, we deal with important laws and rules in conducting local social life. In grade 5, laws and rules are covered including the importance of protecting public health and the environment from pollution and the state of nature in Japan. In grade 6, the Constitution of Japan

\footnotetext{
議会「幼稚園，小学校，中学校，高等学校及び特別支援学校の学習指導要領等の改善について（答申）」 2008 年 1 月。)

${ }^{25}$ Educational contents and learning items in "Social Studies Course of Study" are distributed into numbers and katakana for each grade.
} 
is focused on along with the main events in the history of the country. The relationship between the National Assembly and the Cabinet, the courts' powers, and the judicial participation of the people are also addressed. ${ }^{26}$

The 2017 Elementary Social Studies Course of Study saw a revision of the curriculum with improvements to existing content and new sections on political work in Japan, cultural assets and International Law. ${ }^{27}$

\section{LRE in Lower Secondary Social Studies}

Similar, but more in-depth, content can be found at secondary school level in The 2017 Secondary Social Studies Course of Study. ${ }^{28}$ This now includes views and perspectives in society, work and the market economy, respect for human beings and the Constitution, democratic politics and political participation, world peace and human welfare. Typical keywords of LRE in Lower Secondary Social Studies are 'Rule building', 'Conflict and agreement, efficiency and fairness', 'Mutual respect of human rights', 'Participation in the judicial system' and 'Participation in society/social participation'.

${ }^{26}$ Monbukagakusho. (2008). Shokakko Gakushusidoyoryo Kaisetsu Shakaihen. （文部科学省『小学校学習指 導要領解説社会編』2008 年 6 月。)

27 Monbukagakusho. (2017). Shokakko Gakushusidoyoryo Kaisetsu Shakaihen. （文部科学省『小学校学習指 導要領解説社会編』2017 年 6 月。)

${ }^{28}$ Monbukagakusho. (2017). Chukakko Gakushusidoyoryo Kaisetsu Shakaihen.（文部科学省『中学校学習指 導要領解説社会編』2017 年 6 月。) 


\section{LRE and the Ministry of Justice}

An LRE Promotion Council, established in May 2005, has been conducting an ongoing range of activities ${ }^{29}$. According to the Guidelines for the Promotion of $L R E^{30}$, the purpose of the Council is to promote learning opportunities on justice and law in schools in Japan by ensuring LRE features in school education, by promoting cooperation between educators and lawyers, through the preparation of teaching materials for LRE on the lay judge system and by encouraging other activities, such as research into LRE.

The activities of the LRE Promotion Council can be divided into 5 phases -the first from May 2005 to April 2007, the second from July 2007 to February 2010, the third from April 2010 to February 2014, the fourth from March 2014 to February 2016, and the fifth from March 2016 onward.

The goal of the first and second phases was to develop teaching materials. In the 1st phase, the LRE Promotion Council created teaching materials for junior high school. In the second phase, the LRE Promotion Council dealt with LRE materials in Private Law and improvements in LRE in elementary school. The goal of the third phase

\footnotetext{
${ }^{29}$ Homusho. Hokyoikusuisinkyougikai. （法務省「法教育推進協議会」（http://www.moj.go.jp/shingi1/ kanbou_houkyo_kyougikai_index.html）（visit; 2018. 1.5））

${ }^{30}$ Homusho. (2005). Hokyoikusuisinkyougikaikaisaiyouryou. （法務省「法教育推進協議会開催要領」2005年 5 月（http://www.moj.go.jp/KANBOU/HOUKYO/kyougikai/gaiyou01-01.pdf）（visit; 2018. 1.5）)
} 
though to the current phase is to improve teaching materials and disseminate them. In the third phase, the LRE Promotion Council discussed ways to disseminate LRE, including holding a LRE writing contest. In the fourth phase, the Council discussed ways to disseminate and provide information on LRE. In the fifth phase, the LRE Promotion Council dealt with (and is still developing) audiovisual teaching materials for LRE.

\section{V . JUSTICE STUDIES IN ELEMENTARY AND JUNIOR HIGH SCHOOL}

\section{A. An LRE Programme for Junior High School}

\section{Development of the First LRE ${ }^{31}$}

The Ministry of Justice launched the LRE Study Group, organized the LRE Teaching Materials Preparation Subcommittee, and developed the LRE Unit in Lower Secondary Social Studies. In March 2005, the First LRE was published. It contains the LRE Study Group Report and 4 LRE Units with teaching materials and appendices.

In 2013, the Ministry of Justice reviewed the practices of LRE in junior high schools in $\operatorname{Japan}^{32}$. Of the 5,000 schools surveyed, 1,072, 21.4\% returned valid responses ${ }^{33}$. According to the survey, $80.1 \%$ of responding schools used at least one of the 4 LRE

\footnotetext{
31 Hokyoikukenkyukai. (2005). Hajimeteno Hokyoiku: Wagakuniniokeru Hokyoikuno Fukyu • Hattenwo Mezashite. (First LRE). Gyosei. （法教育研究会『はじめての法教育一我が国における法教育の普及・発展を 目指して一』ぎょうせい，2005 年 3 月。）

32 Homusho. (2013). ‘Chugakkoniokeru Houkyoikuno Jissenjyokyonikansuru Chosakenkyu’ Hokokusho.（法務 省『『中学校における法教育の実践状況に関する調査研究』報告書』, 2013 年 11 月。）

33 ibid. p. 1.
} 
units $^{34}$ and rated the content of the unit significant in terms of subject matter and student learning. ${ }^{35}$. The programme has since developed further although we await detailed evaluation.

\section{Establishment of LRE in Japan}

According to the First LRE, LRE in Japan is defined as "Education for the public who are not legal experts to understand the law, the justice system, the values underlying these, and to acquire legal thinking" ${ }^{\prime 6}$. The goals of LRE in Japan are to understand the basic principles of the constitution and law, to develop the abilities necessary to participate in the management of a free and fair society, to understand that the law is part of everyday life, to act according to law consciously in daily life and to foster the ability to use the law actively and constructively.

The content of The First LRE was organized into four units: 'Rule making', 'Private law and consumer protection', 'The significance of the constitution', and 'Justice'. 'Rule making' means the necessity and manner of rule creation. 'Private law and consumer protection' covers the relationship between individuals and individuals with law. 'The significance of the constitution' means the relationship between individuals and the state. 'Justice' here means dispute resolution under the law.

\footnotetext{
34 Rule making, Private law and consumer protection, The significance of the Constitution and Justice.

35 ibid. p. 45.

${ }^{36}$ Hokyoikukenkyukai. (2005). Hajimeteno Hokyoiku: Wagakuniniokeru Hokyoikuno Fukyu •Hattenwo Mezashite. (First LRE). Gyosei. p. 2. （法教育研究会『はじめての法教育一我が国における法教育の普及・発 展を目指して一』ぎょうせい, 2005 年 3 月, p. 2.)
} 


\section{The Idea of Justice Studies for Lower Secondary School}

The aims of justice studies here is that students understand that, first, justice is a means of preserving law and order by protecting rights, upholding legal responsibilities and dealing with rule violations; secondly, that in a trial no party should be given preferential treatment and procedures, including judgments, should be consistent and fairly conducted and arrived at. The goals of justice studies for Lower Secondary School are to: increase interest in the trial process while comparing it with other dispute resolution methods; recognize legal problems and to analyse and evaluate the causes and points of conflict; to make judgments based on the evidence; and, to encourage students to think about and decide how to deal with laws and rule violations on a case-by-case basis.

\section{B. LRE Programme for Elementary School}

\section{Development of Whose rule? Considering $L R E^{37}$}

The LRE Promotion Council summarizes the following three ways to develop teaching materials for LRE in elementary schools in its report, Creation of LRE

\footnotetext{
37 Hokyoikusuishinkyogikai. (2014). Rulewa Darenomono: Minnade Kangaeru Hokyoiku. (Whose rule? Considering LRE). Homusho. (法教育推進協議会『ルールは誰のもの?一みんなで考える法教育一』法務省 2014 年 3 月。)
} 
Teaching Materials for Elementary School Students ${ }^{38}$. First, in the elementary school, there is a possibility to devise various classes based on the philosophy of LRE promoting active citizenship in the context of everyday life. Secondly, learning can be enhanced by incorporating educational methods such as role-play on familiar issues. Thirdly, practical examples are used, based on commonly occurring situations, where students have to think about not only the nature of the issue concerned but how to address and possibly resolve the problems arising.

In March 2014, Whose rule? Considering LRE was published. The content is in four LRE sections: 'Resolving a quarrel between friends', 'To promise and to defend' for 3rd and 4th grades; 'Living in an information society: as a receiver and sender' for 5th grade; and 'Conflict resolution: participation in judicial judgment, making rules' for 6th grade.

\section{The Idea of Justice Studies for Elementary School}

The goals of justice studies for elementary school are to increase interest in the lay judge system and develop understanding of the significance of citizen's judicial participation; accurately grasping and evaluating facts and expressing ideas based on practical and realistic case studies from familiar situations in school life; understanding the significance of thinking actively and finding solutions, in order to

\footnotetext{
${ }^{38}$ Hokyoikusuishinkyogikai. (2009). Shogakkowo Taishotoshita Hokyoikukyozaireino Sakuseinitsuite. (Creation of LRE Teaching Materials for Elementary School Students). Homusho.（法教育推進協議会『小学校を対 象とした法教育教材例の作成について』法務省，2009 年 8 月。）
} 
solve problems; and, thinking about the significance of the rules in social life by creating rules to solve problems.

The contents of justice studies for elementary school is based on 3 themes: 'The structure of the court, the role of people involved in the trial'; 'Resolution of disputes concerning everyone's interests'; and 'What is the truth?'.

\section{THE CHALLENGES OF LRE}

LRE in Japan, as a matter of public education, is overseen by a variety of agencies and organizations including the Ministry of Justice, the Ministry of Education, Culture, Sports, Science and Technology, the Japanese Federation of and individual Bar Associations, the Japanese Federation of and individual Shiho-Shoshi Lawyers Associations, and the Supreme Court. However, there still remain a number of challenges to be addressed and cooperation to be developed between lawyers and educators. These challenges include, the need for greater planning and coordination of existing and future projects, effective liaison between lawyers and educators research into the impact and value of LRE, the monitoring of the quality of LRE teachers and, the improvement of training for those involved in the design and implementation of LRE. ${ }^{39}$

39 Kyoko ISOYAMA. (2018). Practice of Law-Related Education to Develop Legal Literacy. The United Nations Asia And Far East Institute for the Prevention of Crime and the Treatment of Offender. Resource Material Series. No. 105. p. 133. 
IJPLE 3 (1) 2019

\section{CONCLUSION}

This paper has attempted to show the current situation of LRE in Japan and the challenges associated with it. Whilst there have been many significant and farreaching developments there is still much to be done.

The survey of LRE in Social Studies shows that many teachers indicate that they are now involved in legal literacy education..$^{40}$ It is hoped that this will be a springboard to future sustainable growth in LRE in Japan - so essential not only to make active citizenship more of a reality but to promote respect for human rights in general and to build a more peaceful and democratic nation and society.

${ }^{40}$ Homusho. (2013). op. cit.. p. 12. 
IJPLE 3 (1) 2019

\section{Bibliography}

Public Law 95-561. (1978). LRE Act of 1978.

American Bar Association Division for Public Education. Law-Related Education

Network.

(https://www.americanbar.org/groups/public_education/resources/law_related_edu cation_

network.html)(visit; 2018.1.5).

Report of the American Bar Association Special Committee on Youth Education for Citizenship. (1975). Law-Related Education in America: Guidelines for the Future. American Bar Association.

Study Group on Law-Related Education . (1978). Final Report of the U. S. Office of Education. U. S. Government Printing Office. (ED175 737). 
Anderson, Charlotte C. (1980). Promoting Responsible Citizenship Through

Elementary Law-Related Education. Social Education. Vol. 44-5.

Center for Civic Education. (1998). Foundations of Democracy; Upper Elementary, Middle School, High School.

National Institute for Citizen Education in the Law. (2005). Street Law; A Course in Practical Law, Seventh Edition. West Publishing Company.

Phi Alpha Delta Public Service Center. (1995). Respect Me, Respect Yourself.

American Bar Association Division for Public Education. (1995). Making Rules $\mathcal{E}$ Laws.

American Bar Association Division for Public Education. (1995). Resolving Conflict.

American Bar Association Division for Public Education. (1996). Serving the Community.

American Bar Association Division for Public Education. (1996). Influencing Public Policy.

Center for Civic Education and the National Conference of State Legislatures. (2008). Project Citizen.

Kyoko ISOYAMA. (2000). Construction of LRE in the United States. Annual Report of Graduate Studies in Education. Vol 24. Doctoral Program Education University of 
Tsukuba. pp. 133-144. original Japanese. （磯山恭子「アメリカの法教育におけるカリキュラム 構成に関する研究一法の社会的機能の類型を手がかりとして—』『教育学研究集録』第 24 集, 筑波大学大学院博士課程教育学研究科, 2000 年, pp. 133-144. )

Kyoko ISOYAMA. (2001). Amerikaniokeru Hokyoikuno Toutatutenkara Manabu. Zenkokuhoukyouikunetwork, ed. Hokyoikuno Kanousei: Gakkouniokeruniokeru Rironto Jissen. Gendaijinbunsha. pp. 164-176. （磯山恭子「アメリカにおける法教育の到達点から学 ぶ」全国法教育ネットワーク編『法教育の可能性—学校教育における理論と実践—現代人文 社, 2001 年 7 月, pp. 164-176.)

Yuji EGUCHI, Kyoko ISOYAMA, eds. (2008). Shogakkono Hokyoikuwo Tsukuru: Hou• Rule $・$ Kimariwo Manabu. Toyokanshuppansha. （江口勇治，磯山恭子編『小学校の法 教育を創る一法・ルール・きまりを学ぶ一』東洋館出版社， 2008 年 5 月。）

Yuji EGUCHI, Yaruhiro OKURA, eds. (2008). Chugakkono Hokyoikuwo Tsukuru: Hou • Rule ·Kimariwo Manabu. Toyokanshuppansha.（江口勇治，大倉泰裕編『中学校の法 教育を創る一法・ルール・きまりを学ぶ一』東洋館出版社， 2008 年 5 月。）

Yuhikaku. (2004). Jurist. Vol 1268.（『ジュリスト』No. 1268，有斐閣，2004 年 6 月。） 
Shihouseidokaikakushingikai. (2001). Shihouseidokaikakusingikai Ikensho: 21seikino Nihonwo Sasaeru Shihouseido. （司法制度改革審議会『司法制度改革審議会意見書一21 世紀の日本を支える司法制度一』2001 年 6 月。）

Chuoukyouikushingikai. (2008). Yochien, Shogakko, Chugakko, Kotogakkoyobi Tokubetsushiengakkono Gakushushidoyoryono Kaizennitsuite(Toshin). (Report on improvements of Courses of Study at kindergarten, elementary school, junior high school, junior high school, high school and special school etc.).（中央教育審議会「幼 稚園, 小学校, 中学校, 高等学校及び特別支援学校の学習指導要領等の改善について (答申) 」2008 年 1 月。)

Monbukagakusho. (2008). Shokakko Gakushusidoyoryo Kaisetsu Shakaihen. （文部科学 省『小学校学習指導要領解説社会編』2008 年 6 月。)

Monbukagakusho. (2017). Shokakko Gakushusidoyoryo Kaisetsu Shakaihen.（文部科学 省『小学校学習指導要領解説社会編』2017 年 6 月。)

Monbukagakusho. (2008). Chukakko Gakushusidoyoryo Kaisetsu Shakaihen. （文部科学 省『中学校学習指導要領解説社会編』2008 年 6 月。)

Monbukagakusho. (2017). Chukakko Gakushusidoyoryo Kaisetsu Shakaihen. （文部科学 省『中学校学習指導要領解説社会編』2017 年 6 月。) 
Homusho. Hokyoiku.（法務省「法教育」

(http://www.moj.go.jp/housei/shihouhousei/index2.html)(visit; 2018.1.5).)

Hokyoikukenkyukai. (2005). Hajimeteno Hokyoiku: Wagakuniniokeru Hokyoikuno

Fukyu・Hattenwo Mezashite. (First LRE). Gyosei. （法教育研究会『はじめての法教育一我 が国における法教育の普及・発展を目指して一』ぎようせい，2005 年 3 月。）

Hokyoikusuishinkyogikai. (2007). Hajimeteno Hokyoiku QEA. Gyosei. （法教育推進 協議会『はじめての法教育 Q\&A』ぎょうせい，2007 年 3 月。)

Hokyoikusuishinkyogikai. (2007). Saibaninseidowo Daizaitoshita Kyoikukyozai.

Homusho.（法教育推進協議会『裁判員制度を題材とした教育教材』2007 年。）

Hokyoikusuishinkyogikai. (2009). Shihobunyakyoikuno jyujitsuto Hokyoikuno Saranaru Hattennimukete. Homusho. （法教育推進協議会『私法分野教育の充実と法教育の更な る発展に向けて』法務省，2009 年 5 月。）

Hokyoikusuishinkyogikai. (2009). Shogakkowo Taishotoshita Hokyoikukyozaireino Sakuseinitsuite. (Creation of LRE Teaching Materials for Elementary School Students). Homusho.（法教育推進協議会『小学校を対象とした法教育教材例の作成について』法務 省, 2009 年 8 月。) 
Hokyoikusuishinkyogikai. (2014). Rulewa Darenomono: Minnade Kangaeru Hokyoiku.

(Whose is rules?). Homusho. （法教育推進協議会『ルールは誰のもの? 一みんなで考える 法教育一』法務省 2014 年 3 月。）

Hokyoikusuishinkyogikai. (2015). Hoya Rulette Naze Hitsuyonandarou? Watasgutachito Ho. (Why Do We Have to Make Laws and Rules?). Homusho. （法教育推進協議会 『法やルールって、なぜ必要なんだろう？一私たちと法一』法務省，2015 年 3 月。） 